\title{
Determination of the mineral compositions of some selected oil-bearing seeds and kernels using Inductively Coupled Plasma Atomic Emission Spectrometry (ICP-AES)
}

\author{
By M. Musa Özcan
}

\author{
Department of Food Engineering, Faculty of Agriculture, Selçuk University, 42031 Konya, Turkey. \\ E-mail: mozcan@selcuk.edu.tr
}

\begin{abstract}
RESUMEN
Determınación de la composición en minerales de algunas semillas oleaginosas utilizando ICP-AES (Inductively Coupled Plasma Atomic Emission Spectrometry).

La finalidad del trabajo es establecer el contenido en elementos minerales de semillas oleaginosas tales como ca cahuetes, trementina, avellana, sesamo, maiz, almendras, girasol, utilizando ICP-AES. Se han observado diferencias significativas en la composición de minerales entre cosechas. Todas las semillas contienen cantidades elevadas de $\mathrm{Al}, \mathrm{Ca}, \mathrm{Fe}, \mathrm{K}, \mathrm{Mg}, \mathrm{Na}, \mathrm{P}$ y Zn. Los contenidos de $\mathrm{B}, \mathrm{Cr}, \mathrm{Cu}$, $\mathrm{Li}$, Ni, Sr, Ti y V, sin embargo, fueron bajos. Los contenidos de $\mathrm{K}$ y $\mathrm{P}$ en todas las semillas estudiadas fueron superiores a las de otras semillas. El contenido medio de K osciló entre $1.701,1 \mathrm{mg} / \mathrm{kg}$ (maiz) a 20.895,8 mg/kg (soja), el P entre $3.076 .9 \mathrm{mg} / \mathrm{kg}$ (trementina) a $12.006 .5 \mathrm{mg} / \mathrm{kg}$ o $2.617,4$ $\mathrm{mg} / \mathrm{kg}$ (semilla de algodón), y Ca de $68,4 \mathrm{mg} / \mathrm{kg}$ (maiz) a $13.195,7 \mathrm{mg} / \mathrm{kg}$ (adormidera). Estos resultados indican que los valores obtenidos pueden ser interesantes para deducir informaciones nutricionales de las mismas. En particular, los resultados muestran que las semilla de soja, piña y adormidera representan una buena fuente de $\mathrm{K}, \mathrm{P}$ y $\mathrm{Ca}$, respectivamente mientras que los piñones tienen un contenido elevado de $\mathrm{Zn}$.
\end{abstract}

PALABRAS-CLAVE: Composición mineral - ICP-AES Semıllas oleaginosas.

\section{SUMMARY}

Determination of the mineral compositions of some selected Oil-Bearing seeds and kernels using Inductively Coupled Plasma Atomic Emission Spectrometry (ICP-AES)

The aim of this paper was to establish the mineral contents of oil-bearing seeds and kernels such as peanut, turpentine, walnut, hazelnut, sesame, corn, poppy, almond, sunflower etc., using Inductively Coupled Plasma Atomic Emission Spectrometry (ICP-AES). Significant differences in mineral composition were observed among crops. All seeds and kernels contained high amounts of $\mathrm{Al}, \mathrm{Ca}, \mathrm{Fe}, \mathrm{K}, \mathrm{Mg}, \mathrm{Na}$, $\mathrm{P}$ and $\mathrm{Zn}$. B, Cr, Cu, Li, Ni, Sr, Ti while V contents of the crops were found to be very low. The levels of $K$ and $P$ of all crops in this study were found to be higher than those of other seeds and kernels. The results obtained from analyses of the crops showed that the mean levels of potassiumcontent ranged from $1701.08 \mathrm{mg} / \mathrm{kg}$ (corn) to $20895.8 \mathrm{mg} / \mathrm{kg}$ (soybean), the average content of phosphorus ranged from $3076.9 \mathrm{mg} / \mathrm{kg}$ (turpentine) to $12006,5 \mathrm{mg} / \mathrm{kg}$ to $2617.4 \mathrm{mg} / \mathrm{kg}$ (cotton seed), and Ca from $68.4 \mathrm{mg} / \mathrm{kg}$ (corn) to 13195.7 $\mathrm{mg} / \mathrm{kg}$ (poppy seed). The results show that these values may be useful for the evaluation of dietary information. Particularly the obtained results provide evidence that soybean, pinestone and poppy seed are a good source of $\mathrm{K}, \mathrm{P}$ and $\mathrm{Ca}$, respectively. Whereas pinestone is a good source of zinc.

KEY-WORDS: ICP-AES - Mineral composition - Oilbearing seed.

\section{INTRODUCTION}

A number of mineral ions are recognized as essential plant nutrients that are directly incorporated into organic compounds sythesized by the plant. Of these, potassium, phosphorus, calcium, magnesium and sodium are the most important quantitatively and are recommended for composition analysis (Anonymous 2004b). Recently, the significance of oil-bearing seeds and kernels in the nutrition of human populations is increasing for several reasons. The seeds of oil-bearing crops (sunflower, corn, peanuts, hazelnut, walnut, mustard, black cumin, soybean, sesame etc.) have several food value and curative properties (Özdemir et al., 2001; Özcan, 2004; Glew et al. 1997; Anonymous 2004a). Sunflower seeds are probably the most familier of all edible seeds. The larger kernels are generally used for edible purposes while the smaller ones for crushing into edible oil. Sunflower was introduced in Europe in the 16th century. Sunflower kernels are well above average in protein, phosphorus and iron concentrations. So, the flour made from sunflower seeds is one of the richest sources of iron in any food. It is, therefore, highly beneficial in the prevention and treatment of anemia (Anonymous 2004a). The phosphorus present is fairly available because of the phytase activity within the grain. The low Ca:P ratio requires the inclusion of ground limestone or similar to supplement the Ca level (Wiseman, 1987). Baş et al.(1986) and Açkurt et al.(1999) reported compositions of major commercial Turkish hazelnut varieties. In addition, Ayfer et al.(1986) and Çalışkan (1995) reported physical properties of the major commercial Turkish hazelnuts. Pumpkin (Cucurbita sp) and melon (Cirrullus sp) seeds are used directly for human consumption as a snack after salting and roasting in Arabian countries (Al-Khalifa, 1996). Smith et al. 
(1996) have also reported on the nutritional composition and uses of wild foods common to Burkina Faso and Niger. Moreover, Enujiupha (2003) reported chemical and functional properties of the conophor nut purchased from the Oja-oba market at Akure. Dugo et al. (2004) determined some mineral contents of commercial vegetable oils using derivative potentiometric stripping analyses.

In the earlier part of this century, scientists could qualitatively detect small amounts of several mineral elements in living organisms. The trace elements found in living organisms may be essential, fortuitious reminders of our geochemical origins or indicators of environmental exposure (Macrae et al.1993 a,b). Human, as well as animal, studies originally showed that optimal intakes of elements such as sodium, potassium, magnesium, calcium, manganese, copper, zinc and iodine could reduce individual risk factors, including those related to cardiovascular disease (Anke et al., 1984; Mertz,1982; Sanchez-Castillo et al., 1998). Throughout the world, there is increasing interest in the importance of dietary minerals in the prevention of several diseases.Minerals are of critical importance in the diet, even though they comprise only $4-6 \%$ of the human body. The major minerals serve as structural components of tissues and function in cellular and basal metabolism and water and acid-base balance (Macrae et al.1993a; Nielsen,1984; Smith,1988). However, very little information has been reported on the mineral contents of oil-bearing seeds and kernels (Özdemir et al.2001; Enujiugha, 2003; Glew et al.1997; Baş et al.,1986; Açkurt et al.1999; Ayfer et al.,1986; Özcan and Akgül, 1995; Özcan, 2000; Özcan and Seven, 2003; Özcan, 2004).
Therfore, the aim of this work is to established the mineral contents of oil-bearing seeds and kernels via ICP. In addition, other physico-chemical and functional properties of seeds and kernels are also studied.

\section{MATERIAL AND METHODS}

\subsection{Material}

Oil-seeds and kernels (Table 1) were purchased from bazaar in Konya in Turkey in August 2003. The materials were transported in polypropylene bags and held at room temperature. Materials were cleaned by a combination of manual and mechanical means to get rid of all foreign matter as well as crushed or immature fruits.

\subsection{Method}

\section{Determination of mineral contents}

About $0.5 \mathrm{~g}$ dried and ground materials was put into a burning cup and $15 \mathrm{ml}$ of pure $\mathrm{HNO}_{3}$ were added. The sample was incinerated in MARS 5 Microvawe Oven at $200{ }^{\circ} \mathrm{C}$ temperature and the solution was diluted to the desired volume with water. Concentrations were determined with an ICP-AES (Skujins, 1998).

Working conditions of ICP-AES: Instrument: ICPAES (Varian-Vista). RF Power: 0,7-1,5 kw (1,2-1,3 kw for Axial). Plasma gas flow rate (Ar): 10,5-15 L/min. (radial), $15 \mathrm{~L} / \mathrm{min}$. (axial). Auxilary gas flow rate (Ar): 1,5 L/min. Viewing height: 5-12 mm. Copy and reading time: $1-5 \mathrm{~s}$ (max.60 s). Copy time: $3 \mathrm{~s}$ (max. $100 \mathrm{~s}$ ).

Table 1

Crops used in experiment

\begin{tabular}{llll}
\hline General name & Botanical name & Family & Used parts \\
\hline Almond & Prunus amygdalus L. & Rosaceae & Kernel \\
Apricot & Prunus armeniaca L. & Rosaceae & Kernel \\
Black cumin & Nigella sativa L. & Ranunculaceae & Seed \\
Safflower & Carthamus tinctorius & Asteraceae & " \\
Corn & Zea mays & Gramineae & Germ \\
Cotton & Gossipium hirsitum & Malvaceae & Kernel \\
Hazelnut & Corylus avellana L. & Corylaceae & Seed \\
Linen & Linum utitassimum L. & Linaceae & Seed \\
Peanut & Arachis hypogaea L. & Leguminoseae & Kernel \\
Pinestone & Pinus pinea L. & Pineceae & Kernel \\
Pistachio nut & Pistachia vera L. & Anacardiaceae & Seed \\
Poppy & Papaver somniferum L. & Papaveraceae & Seed \\
Rape & Brassica napus L. & Cruciferae & Seed \\
Sesame & Sesamum indicum L. & Pedaliaceae & Seed \\
Soybean & Soja max & Leguminoseae & Seed \\
Sunflower & Helianthus annuus L & Compositeae & Fruit \\
Turpentine & Pistachia terebinthus L. & Anacardiaceae & Fruit \\
Walnut & Juglans regia L & Juglandaceae & \\
\hline
\end{tabular}




\section{RESULTS AND DISCUSSIONS}

The mineral contents of oil-bearing seeds and kernels are presented in Table 2. Mineral values were established to vary widely depending on the different seeds and kernels.

Results have shown that $\mathrm{Al}, \mathrm{Ca}, \mathrm{Fe}, \mathrm{K}, \mathrm{Mg}, \mathrm{Na}$, $\mathrm{P}$ and $\mathrm{Zn}$ were major minerals of all oil-bearing seeds and kernels (Fig 1). B, Cr, Cu, Li, Ni, Sr, Ti and $\mathrm{V}$ contents of crops were found to be very low. $\mathrm{Mn}$ was not established in cotton seed, turpentine, pistachio nut, sesame, aspir, corn, almond or apricot. In addition Sr was not determined in corn or pistachio nut, respectively. The levels of $\mathrm{K}$ and $\mathrm{P}$ of all crops in this study were found to be higher than those of other seeds and kernels. The potassium content was high in most cases and ranged from $1701.08 \mathrm{mg} / \mathrm{kg}$ corn to $20895.78 \mathrm{mg} / \mathrm{kg}$ soybean. The phosphorus content ranged from 3076.87 $\mathrm{mg} / \mathrm{kg}$ turpentine to $12006.46 \mathrm{mg} / \mathrm{kg}$ pistachio nut (Fig 1). The magnesium content varied from $1153.99 \mathrm{mg} / \mathrm{kg}$ in corn to $2617.38 \mathrm{mg} / \mathrm{kg}$ in cotton seed. The Lithium contents of seeds and kernels were found in similarly small percentages in all the species analyzed, ranging from $1.63 \mathrm{mg} / \mathrm{kg}$ soybean to $2.76 \mathrm{mg} / \mathrm{kg}$ black cumin. Ca was found to be high, ranging from $68.40 \mathrm{mg} / \mathrm{kg}$ in corn to $13195 \mathrm{mg} / \mathrm{kg}$ in poppyseed. Cr content was found to be very similar to those of other crops. Fig 1 provides evidence that $\mathrm{Ca}$ is present in very low amounts but poppy seed presented the highest mean concentrations of $\mathrm{Ca} 13195.67 \mathrm{mg} / \mathrm{kg}$. Pine stone kernels also presented the highest average amounts of zinc $(85.57 \mathrm{mg} / \mathrm{kg})$ and turpentine fruit the lowest $(8.29 \mathrm{mg} / \mathrm{kg})$. Copper concentrations found in this work were lower than those published for black cumin, whereas the levels of $B$ and $\mathrm{Zn}$ are similar to those determined in black cumin (Özcan,2004).

Minerals are of interest due to their pro-oxidant activity and health benefits (Alphan et al.,1996; Pala et al., 1996; Parcerisa et al.,1995; Pesrshern et al.,1995). Özdemir (1985) and Özdemir et al.(2001) determined the $\mathrm{Fe}, \mathrm{Cu}, \mathrm{Mn}, \mathrm{K}, \mathrm{Zn}, \mathrm{Na}, \mathrm{Mg}$ and $\mathrm{Ca}$ contents of some commercial and new hybrid hazelnut varieties, and $\mathrm{Ca}, \mathrm{Mg}$ and $\mathrm{K}$ contents were found higher than those of other elements. Hazelnut was rich in mineral matters such as $\mathrm{Ca}$ (209.0 $\mathrm{mg} / 100 \mathrm{~g}), \mathrm{Mg}(162.5 \mathrm{mg} / 100 \mathrm{~g})$, P (337.0 $\mathrm{mg} / 100 \mathrm{~g}$ ) and $\mathrm{K}(704.0 \mathrm{mg} / 100 \mathrm{~g})$ (Şimşek and Aslantaş,1999). From a human nutritional point of view, hazelnut is rich in $\mathrm{Ca}, \mathrm{K}, \mathrm{Mg}$ and $\mathrm{P}$. The seeds of Sorghum vulgaris contain relatively large amounts of $\mathrm{Mg}(1520 \mu \mathrm{g} / \mathrm{g}), \mathrm{P}(3030 \mu \mathrm{g} / \mathrm{g}), \mathrm{Ca}(202$ $\mu \mathrm{g} / \mathrm{g})$ and $\mathrm{Fe}(35 \mu \mathrm{g} / \mathrm{g})$.

We concur, too, with their? results that dried sesame, copper, mustard and peanut contain high concentrations of $\mathrm{Cu}, \mathrm{Mg}, \mathrm{Z}$ and Fe. Our data on mineral contents are in accordance $\mathrm{g}$ with their? data in that we found that soybean contains large quantities of $\mathrm{Al}, \mathrm{Ca}, \mathrm{K}$ and $\mathrm{Ni}$.

It is noteworthy that trace minerals are important not only for human nutrition, but for plant nutrition as well. Mineral-efficient varieties of plants are more drought resistant and require less irrigation (Botta and Giovanni,1996; Bouis,1996; Glew et al.,1997).

Table 2

The mineral contents of oil-bearing seed and kernels

\begin{tabular}{|c|c|c|c|c|c|c|c|c|c|c|c|c|c|c|c|c|c|}
\hline \multirow{2}{*}{ Samples } & \multicolumn{17}{|c|}{ Minerals (mg/kg) } \\
\hline & Al & B & $\mathrm{Ca}$ & $\mathrm{Cr}$ & $\mathrm{Cu}$ & $\mathrm{Fe}$ & K & $\mathrm{Li}$ & $\mathrm{Mg}$ & $\mathrm{Mn}$ & $\mathrm{Na}$ & $\mathrm{Ni}$ & $\mathbf{P}$ & $\mathrm{Sr}$ & $\mathrm{Ti}$ & V & $\mathrm{Zn}$ \\
\hline Peanut & 25.60 & 26.66 & 644.56 & 1.84 & 7.41 & 17.62 & 6035.9 & 1.93 & 1377.2 & 4.49 & 787.4 & 1.69 & 3972.3 & 0.26 & 5.96 & 5.98 & 26.59 \\
\hline Cotton & 22.55 & 16.73 & 1025.63 & 2.08 & 9.47 & 53.52 & 12926.8 & 1.73 & 2617.4 & ND & 722.8 & 3.37 & 9425.6 & 2.66 & 0.59 & 16.20 & 38.04 \\
\hline Turpentine & 37.65 & 16.64 & 1460.37 & 2.94 & 4.95 & 35.36 & 12095.7 & 1.94 & 708.7 & ND & 826.9 & 0.62 & 3076.9 & 1.08 & 3.24 & 3.89 & 8.29 \\
\hline Pistachio & 18.83 & 10.57 & 1998.09 & 1.66 & 6.79 & 35.67 & 9361.65 & 1.87 & 1145.6 & ND & 788.6 & 0.85 & 4753.8 & 3.38 & 7.02 & 7.57 & 15.80 \\
\hline Walnut & 18.27 & 11.59 & 511.12 & 1.66 & 3.76 & 24.81 & 3379.2 & 1.77 & 1321.1 & 11.79 & 650.4 & 2.42 & 4380.9 & 0.33 & 7.12 & 5.51 & 13.88 \\
\hline Rape & 25.29 & 11.26 & 3070.47 & 1.29 & 2.17 & 42.32 & 5900.2 & 1.75 & 1897.9 & 22.89 & 654.9 & 1.21 & 6633.9 & 12.49 & 1.18 & 14.01 & 23.86 \\
\hline Sesame & 70.34 & 11.22 & 723.57 & 3.82 & 11.58 & 64.48 & 4295.7 & 1.81 & 2191.4 & ND & 1138.8 & 0.95 & 8308.9 & 12.33 & 0.91 & 10.13 & 28.16 \\
\hline Hazelnut & 27.88 & 19.21 & 1192.68 & 2.06 & 10.66 & 41.65 & 5310.3 & 1.82 & 1284.4 & 26.18 & 674.2 & 1.15 & 3800.3 & 2.48 & 4.53 & 6.51 & 16.91 \\
\hline Sufflower & 18.19 & 14.35 & 640.09 & 1.66 & 16.93 & 62.82 & 6801.9 & 1.77 & 1959.7 & $N D$ & 747.9 & 1.02 & 7864.1 & 0.38 & 1.21 & 9.50 & 61.56 \\
\hline Corn & 23.76 & 3.51 & 68.40 & 2.38 & 2.85 & 37.89 & & 1.72 & & ND & 535.8 & 0.79 & 5244.3 & $\mathrm{ND}$ & 7.11 & 3.63 & 33.55 \\
\hline Poppy & 27.47 & 13.51 & 13195.67 & 1.42 & 14.94 & 75.90 & 6468.8 & 1.83 & 2343.5 & 58.68 & 844.6 & 1.11 & 7945.0 & 4.49 & 0.35 & 39.52 & 58.09 \\
\hline Linen & 85.91 & 10.96 & 1693.18 & 1.57 & 8.23 & 83.49 & 8445.7 & 2.01 & 2318.8 & 7.88 & 1031.6 & 1.35 & 6651.6 & 2.25 & 5.91 & 13.53 & 26.58 \\
\hline Cumin & 75.18 & 14.70 & 4418.60 & 2.37 & 8.67 & 83.30 & 8288.7 & 2.76 & 1902.5 & 7.27 & 835.9 & 4.31 & 7494.8 & 24.22 & 1.52 & 16.12 & 29.64 \\
\hline Almond & 22.19 & 8.20 & 1692.76 & 1.70 & 5.85 & 34.04 & 6794.9 & 1.81 & 1771.0 & ND & 650.4 & 0.49 & 6261.8 & 1.16 & 2.19 & 10.22 & 21.85 \\
\hline Soybean & 44.43 & 24.18 & 1867.21 & 4.83 & 8.75 & 79.64 & 20895.8 & 1.63 & 1762.7 & 4.61 & 757.8 & 4.73 & 5972.2 & 5.09 & ND & 10.56 & 23.36 \\
\hline Apricot & 20.14 & 11.29 & 928.70 & 2.50 & 10.06 & 28.84 & 9730.4 & 1.99 & 1515.7 & ND & 697.8 & 3.27 & 5068.1 & 2.32 & 5.76 & 6.99 & 30.28 \\
\hline Stonepine & 59.65 & 17.02 & 278.71 & 1.93 & 24.48 & 90.57 & 10392.2 & 1.78 & 2418.7 & 36.92 & 871.2 & 3.16 & 12006.5 & ND & 2.08 & 12.28 & 85.57 \\
\hline Sunflower & 31.75 & 7.33 & 464.84 & 2.17 & 18.11 & 49.66 & 8753.8 & 1.64 & 2251.3 & 6.95 & 1026.7 & 5.71 & 9607.9 & 3.72 & 0.51 & 11.29 & 36.54 \\
\hline
\end{tabular}

ND:Non Detected 
Figure 1

Major minerals of oil-seed and kernels $(\mathrm{mg} / \mathrm{kg})$

Al

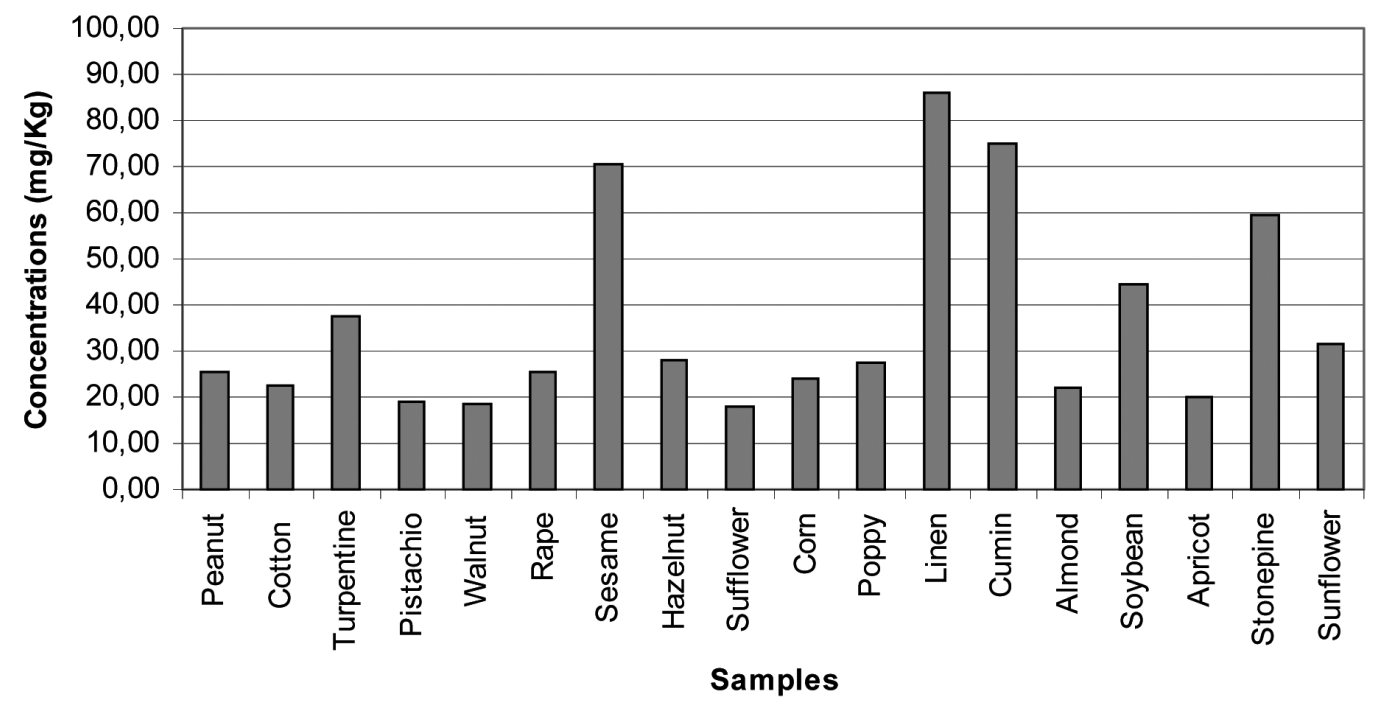

$\mathrm{Ca}$

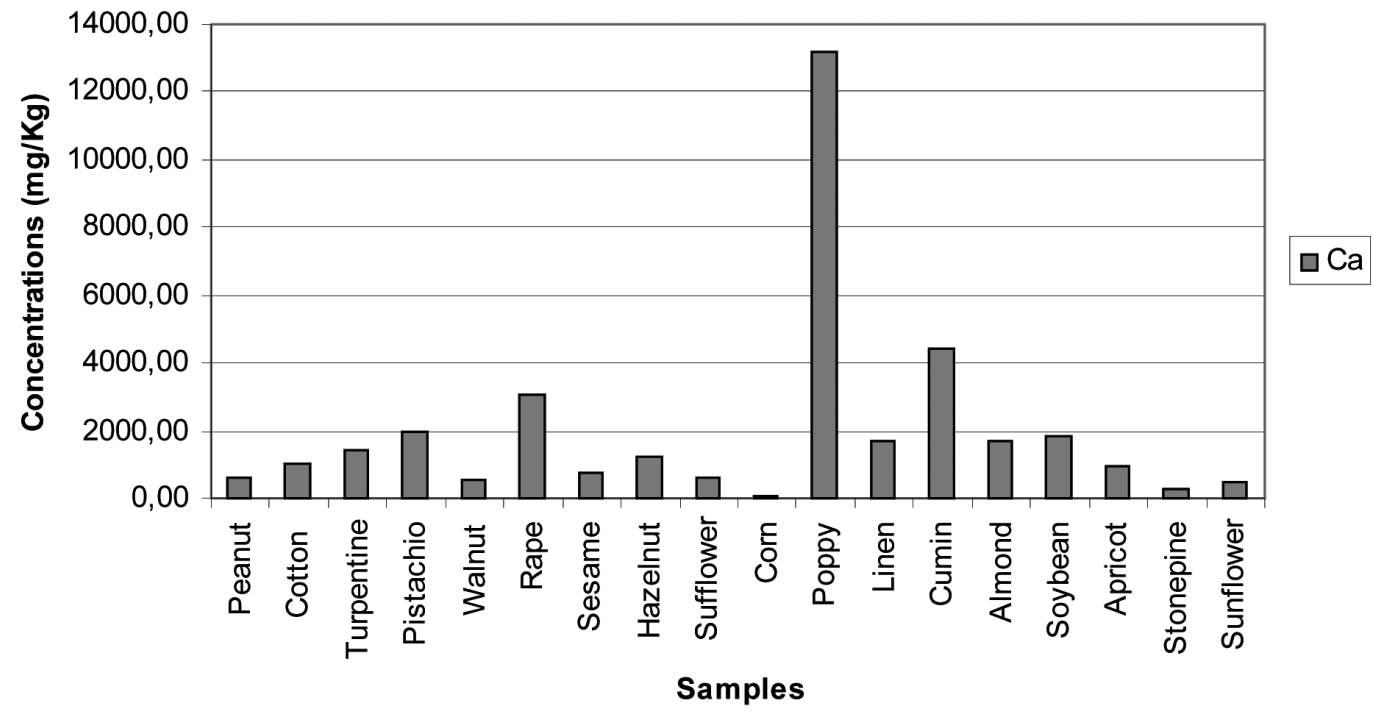

$\mathrm{Fe}$

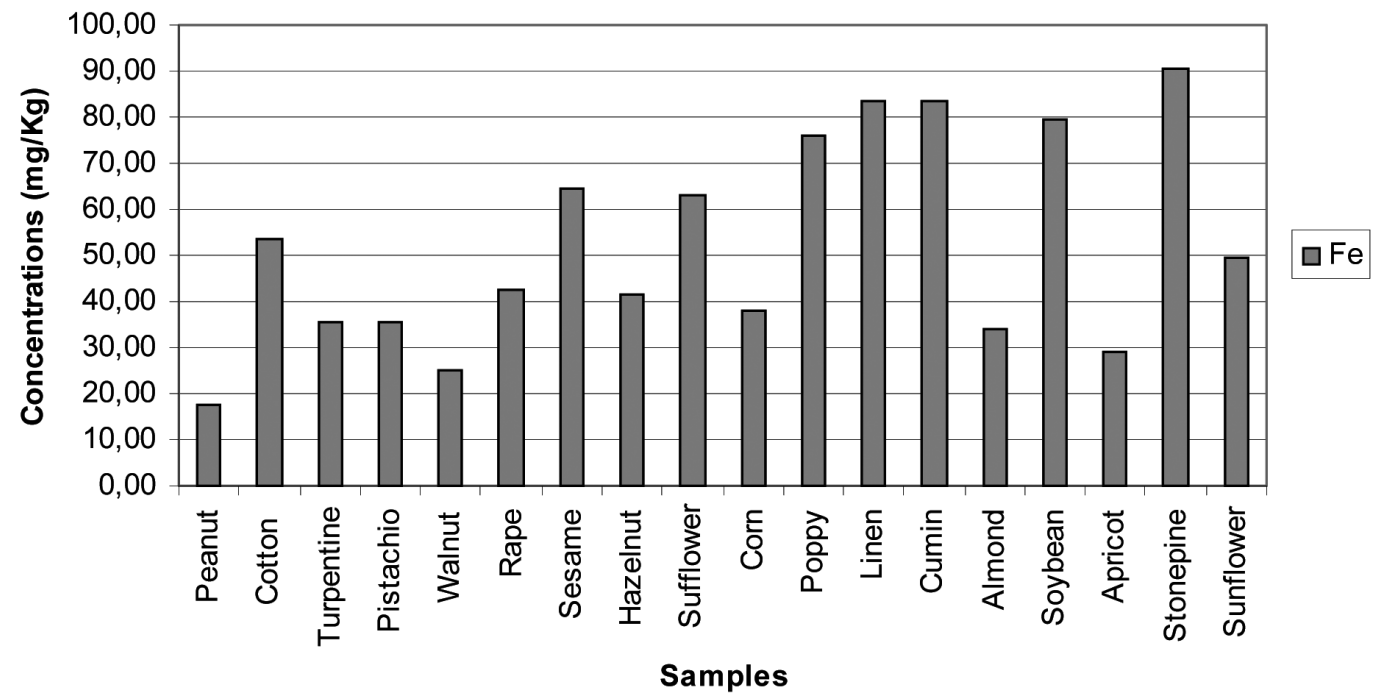



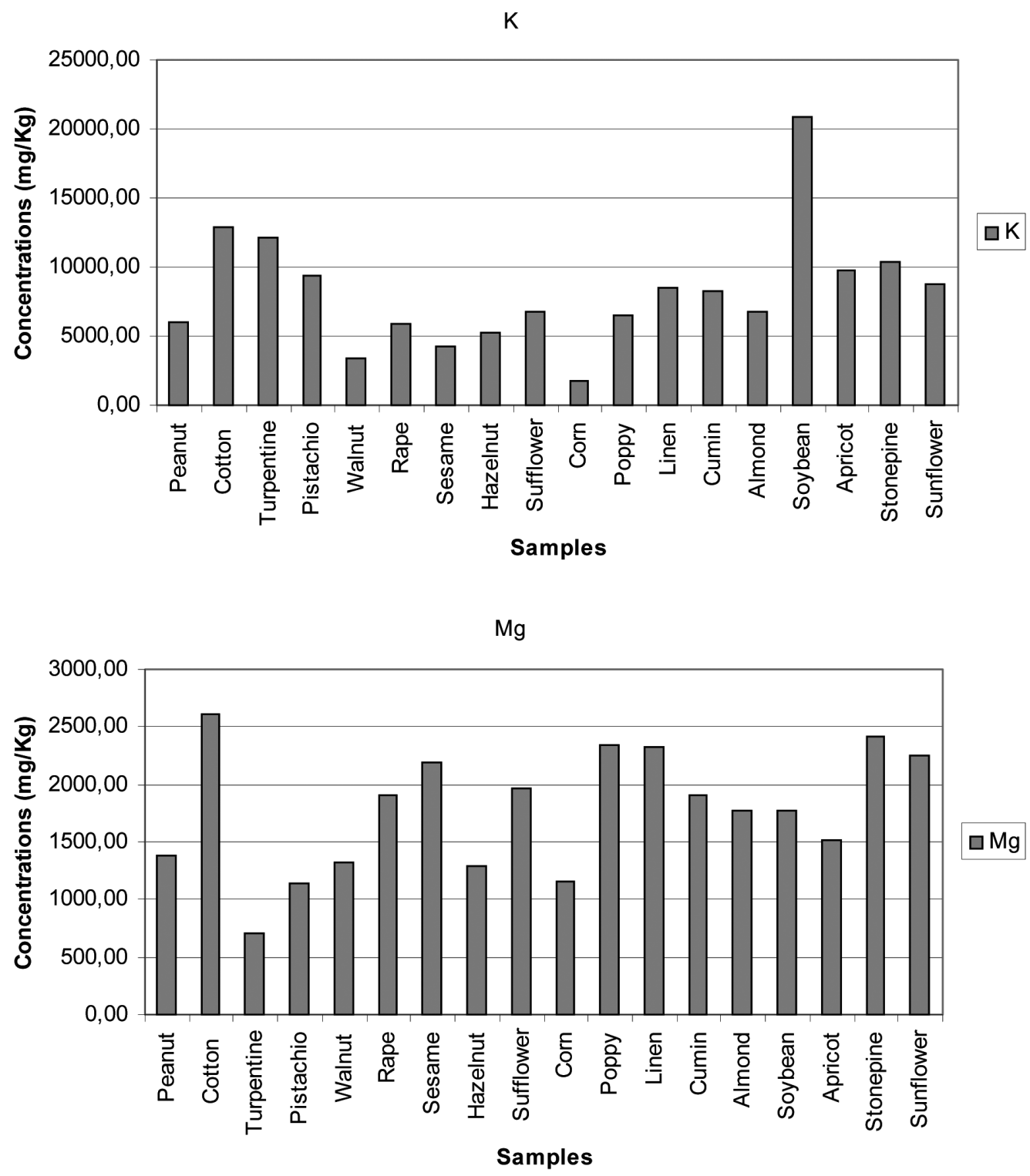

$\mathrm{Na}$

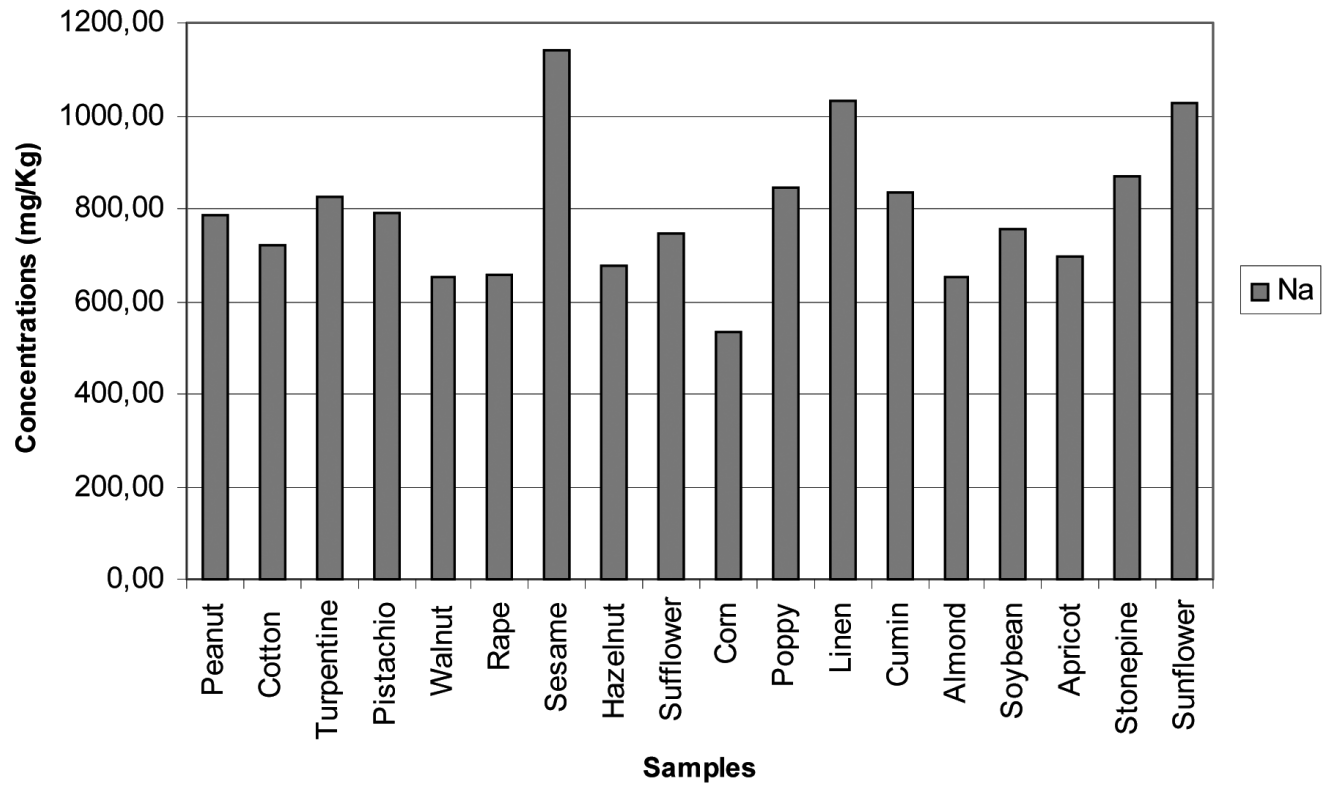


$P$

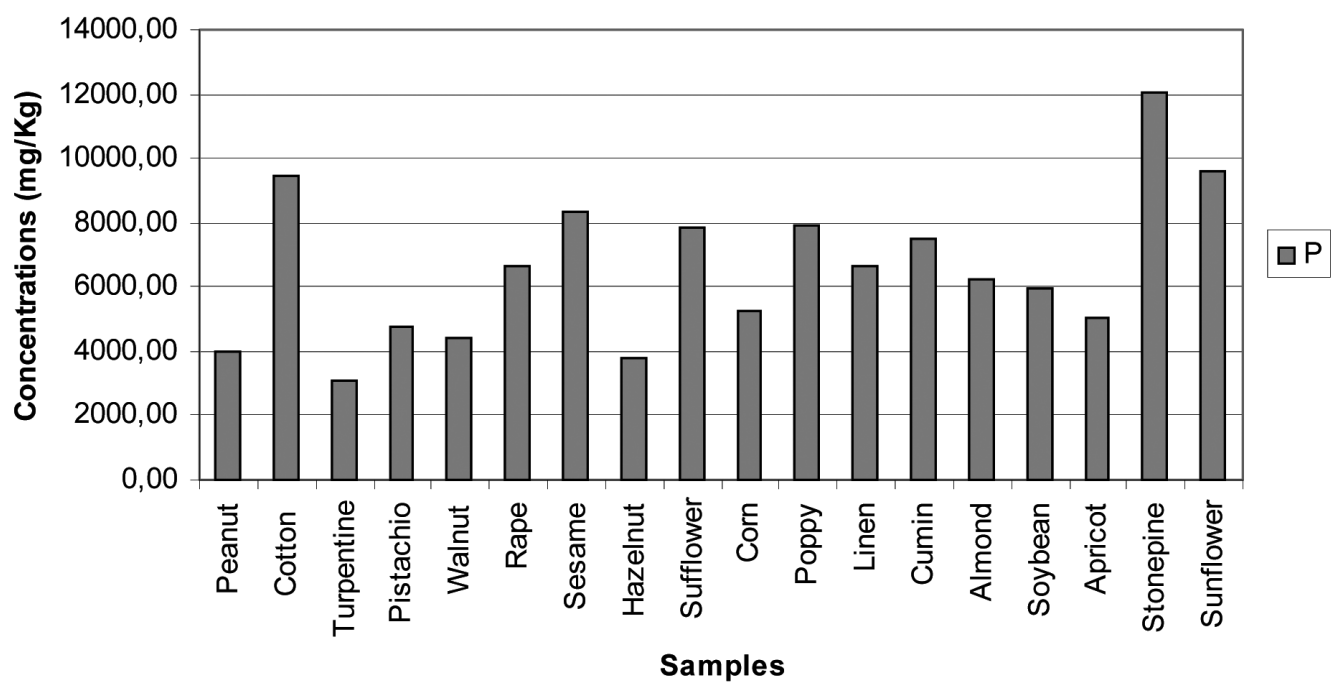

Zn

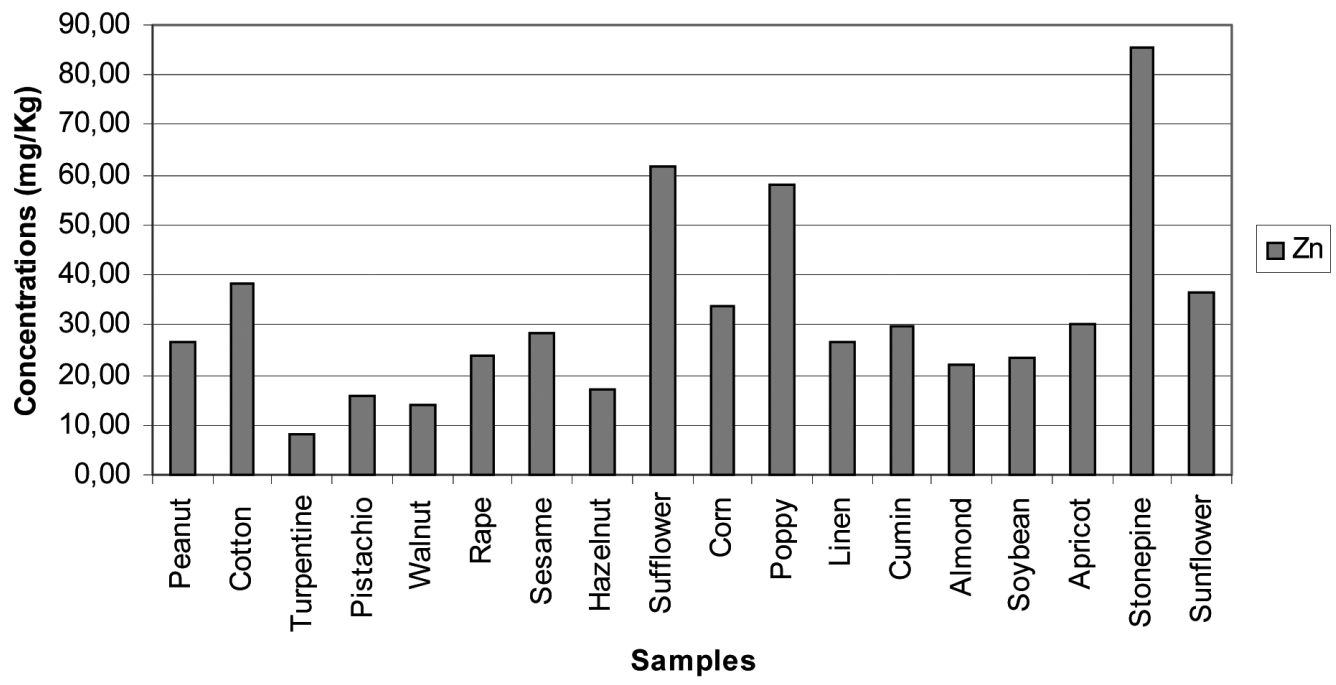

In a previous study, Enujiugha (2003) reported the mineral contents ( $\mathrm{Ca}, \mathrm{Mg}, \mathrm{P}, \mathrm{Cu}, \mathrm{Fe}, \mathrm{Zn}, \mathrm{Ni}, \mathrm{Co}$, $\mathrm{Cb})$ of a conophor nut called as the African walnut, and determined it as (mg/100 g) 42.06, 57.37, $465.95,1.56,1.55,6.84,0.38,0.05$ and 0.01 , respectively. Özcan (2000) reported that some apricot kernels contained $\mathrm{Na}(2.75-3.68 \%), \mathrm{K}(0.35-$ $0.64 \%), \mathrm{Ca}(0.08-0.11 \%), \mathrm{Mg}(0.23-0.26 \%)$ and $\mathrm{Fe}$ (10.7-74.9\%) minerals. Özcan and Akgül (1995) determined the mineral contents (0.07- $0.16 \% \mathrm{Na}$; 0.47- $0.60 \%$ K; 1.01-1.85\% P; 15.58-20.45 ppm Cu; 65.20-85.95 ppm Fe; 16.61-22.66 ppm $\mathrm{Mn}$ and 70.10- $121.41 \mathrm{ppm} \mathrm{Zn}$ ) of sesame seeds provided from several different regions. In another study, $\mathrm{Na}$, K, Ca, P, Fe, Zn, Cu, Mg, Mn, Al, As, B,Cs,Cr,Li,Pb,Se and $V$ values of two different peanuts have been established by using Inductively Coupled Plasma Atomic Emission Spectrometry (ICP-AES). Both seeds of Çom and NC-7 peanut cultivars were found rich in $\mathrm{Na}, \mathrm{K}, \mathrm{Ca}, \mathrm{P}, \mathrm{Fe}, \mathrm{Zn}, \mathrm{Cu}, \mathrm{Mg}, \mathrm{Mn}, \mathrm{Al}, \mathrm{B}$ and $\mathrm{Sr}$
(Özcan and Seven,2003). Potassium and Calcium were the predominant elements in the poppy seeds followed by sodium, magnesium and phosphorus (Nergiz and Ötleş, 1994). Cu, Fe and Zn are essential minerals for human nutrition, and their daily doses for adults, respectively, are $2-3 \mathrm{mg}, 18 \mathrm{mg}$ and $15 \mathrm{mg}$ (Clydesdale and Francis, 1985).

Oil-bearing seeds and kernels were high in phosphorus and calcium, which are essential for bone and teeth development (Brody,1994). The high phosphorus content agrees with the observation of Nwokolo (1987) that phosphorus was high in some tropical grains and oil seeds. Nickel was detected in very low concentrations below the minimum permissible levels for the human body. The results of the present study compare favorably with those obtained by Özcan and Akgül(1995), Özcan (2000) and Özcan (2004).

These differences might be due to growth conditions, genetic factors, geographical variations 
and analytical procedures (Guil et.al.,1998; Özcan,2004; Özcan and Akgül,1998; Özcan et al.,1998).

The $\mathrm{Mg}, \mathrm{Fe}, \mathrm{K}, \mathrm{Ca}$ and $\mathrm{P}$ levels are adequate. Inorganic elements which may contribute to biological processes, but which have not been established as essential, are B and Li (Macrae et al.,1993a). Lithium is another element with beneficial pharmacological properties; it has been used effectively in the treatment of manic depressive disorders. There is evidence to suggest that lithium is also an essential element (Macrae et al.1993b).

\section{ACKNOWLEDGEMENT}

Author thanks to Dr Kadir Sabancı for him help. Also, this study was supported by Selçuk University Scientific Research Project (S.Ü.-BAP).

\section{REFERENCES}

Anonymous. 2004a. Availaoble:http:// www. Indiangyan. Com / book/ healthbooks/ food-that-heal /sunflower -seeds. Shtml. $(21.03,2004)$

Anonymous. 2004b. Available:http://www.projectgroep biotechnologie.nl/actueel/download/SubstantialEqui valence-OilseedRape.pdf (7.4.2004)

Açkurt, F., Özdemir, M., Biringen, G., Löker, M. 1999. Effect of geographical origin and variety on vitamin and mineral composition of hazelnuts (Corylus avellena L.) varieties cultivadet in Turkey. Food Chemistry 65,309-313

Al-Khaliffa, A.S. 1996. Physicochemical characteristics, fatty acid compasition and lipoxygenase activity of crude pumpkin and melon seed oils. Jouurral of Agricultural and Food Chemistry 44. 964-966.

Anke, M., Groppel, B., Kronemann, H. 1984. Significance of newer essential trace elements (like $\mathrm{Si}, \mathrm{Ni}, \mathrm{As}, \mathrm{Li}$, $\mathrm{V}, \ldots$ ) for the nutrition of man and animals P. Bratter \&P. Schramel (eds.) In: Trace elements-analytical chemistry in medicine and biology. Vol. 3, pp 424-464, Berlin.

Ayfer,M., Uzun, A., Bal, F. 1986. Türk Fındık Çeşitleri (Turkish Hazelnut varieties). Ankara: Black Sea Hazelnut Exporters Union,Turkey.

Baş, F., Ömeroğlu, S., Türdü and Aktoz, S. 1986. Composition of the main hazelnut varieties cultivated in Turkey (Önemli Türk Fındık sentlerinin bileşim özelliklerinin saplanması). Gıda 11,195-203. (in Turkish)

Botta., R., Giovonni, M. 1996. Kernel guality in hazelnut cultivars and selections analysed for sugars, lipids, and fatty acid composition. Acta Harticulturae 445,319-326.

Alphan, E., Pala, M., Açkurt, F., Yılmaz, T. 1996. Nutritional composition of hazelnuts and its effects on glucose and lipid metabolism. Acta Harticulturae 445, 305-310.

Bouis, H. 1996. Enrichment of food staples through plant breeding: A new strategy for tighting micronutrient malnutrion. Nutr. Rev 54,131-137.

Brody, T. 1994. Nutritional Biochemistry, Son Diego, CA: Arademic Pass.

Clydesdale, F. M., Francis, F. J. 1985. Food Nutrition and Health. The AVI Pubishing Company Inc, Westport, Connecticut, pp 225-226.
Dugo, G., pera L. L., La Torre, G. L., Giuffrida, D. 2004. Determination of $\mathrm{Cd}$ (II), Cd (II), Pb (11), and $\mathrm{Zn} \mathrm{(11)}$ content in commercial vegetable oils using derivative potentiometric stripping analysis. Food Ctermitiy (in press)

Erujiugha, V. N. 2003. Chemical and funetional characteristic, of conophor nut. Pakistan Journal of Nutrition 2(6), 335-338

El-Adawy, T. A., Taha, K. M. 2001. Characteristic, and compasition of different seed oils and Flours. Food Chermistry 74, 47-54.

Glew, R. H., Vanderjagl, D. J., Lockell, C., Grivetti, L. E., Smith G. C., Pastuszyn, A., Millson, Millson,M. 1997. Amino acid, fatty acid, and mineral composition of 24 Indigenous plants of Burkina Faso. J. Food Composition and Analysis 10,205-217.

Guil, J. I., Martinez, J. J. 6., Isasa, M.E. 1998. Mineral nutrient compasition of edible wild plants. J. Food Composition and Analysis 11,322-328

Macrae, R., Robinson, R. K. Sadler, M. J. (eds.) 1993a. Encyclopaedia of Food Science, Food Technology and Nutrition, Vol. 5, 3126-3131, Academic Press INC., San Diego,CA.

Macrae, R., Robinson, R. K. Sadler, M. J. (eds.). 1993b. Encyclopaedia of Food Science, Food Technology and Nutrition, Vol. 7, 4593-4600, Academic Press INC., San Diego,CA.

Mertz, W. 1982. Trace minerals and atherosclerosis. Food Processing 41(11), 2807-2812.

Nergiz, C., Ötleş, S. 1994. The proximate composition and some minor constituents of poppy seeds. Journal of the Science of Food and Agricultur 66, 117-120.

Nielsen,F.H. 1984. Ultratrace elements in nutrition. Annual Review of Nutrition 4, 21-41.

Nwokolo, E. 1987. Composition and availability of nutrients in some tropical grains and oilseeds. Nutr. Rep. Int., 36, 631-640.

Özcan M. and Akgül, A. 1995. Some compositional characteristic of sesame seed and oil. Tr. J. Agricultura and Forestry 19: 59-65

Özcan, M., Akgül, A. (1998). Influence of species, harvest date and size on composition of capers (Capparis spp.) flowers buds. Nahrung 42,102-105

Özcan, M., Akgül, A., Bagci, Y., Dural, H. 1998. Chemical composition and mineral content of edible wild plants consuned. Annual Review of Nutrition Journal 15,72-77

Özcan, M. 2000. Composition of some apricot (Prunus armeniaca L) kerrels grown in Turkey. Acta Alinentaria 29(3), 289-293

Özcan, M., Seven, S. 2003. Physical and chemical analysis and fatty acid composition of peanut, peanut oil and peanut butter from com and $\mathrm{N} \mathrm{C}-7$ cultivars. Grasas y Aceites 54 (1), 12-18.

Özcan, M. 2004. Mineral content, of some plants used as condimennts in Turkey. Food Chemistry 84, 437-440

Özcan. 2004. Characteristics of fruit and oil of terebinth (Pistacia terebinthus L.) growing wild in Turkey. Journal of the Science of Food and Agriculture 84(6):517-520.

Özdemir, M. 1985. Elemental analysis of hazelnut kernels and shells by spark source mass spectromentry. $Z$. Lebensmittel Untersuchung. und Forschun 180, 289292.

Özdemir, M., Açkurt, F., Kaplan, M., Yıldız, M., Löker, M., Gürcan,T., Biringen, G., Okay, A., Seyhan, F.G. 2001. Evaluation of new Turkish hybrid hazelnut (Corylus avellana L.) varieties: fatty acid compasition, $\alpha$ tocopherol content, mineral composition and stability. Food Chemistry 73,411-415 
Pala, M., Açkurt, F., Löker, M., Yıldız, M., Ömeroğlu, J. 1996. Fındık çeşitlerinin bileşimi ve beslenme fizyolojisi açısından değerlendirilmesi. Turkish Jourral of Agriculture \& Forestry 20, 43-48

Parcesio, J., Rafeces, M., Castellote, A. I., Codony, R., Farran, A., Garcia, J., Lopez, A., Romena, A., Boatella, J. 1995. Influence of variety and geographical origin on the lipid fraction of hazelnuts (Corylus avellena L.) from Spain: II.Triglyceride composition. Food Chemistry 30 , 245-249

Pershern, A. S., Breene, W. M., Lulai, E.C. 1995. Analysis of Factors influencing lipid oxidation in hazelnuts (Corylus sp.). Jourral of Food Processing and Preservation 19, 9-25

Sanchez- Castillo, C.P., Dewey, P.J.S., Aguirre, A. Lara, J. J, Vaca, R., Leon de la Barra, P., Ortiz, M., Escamilla, I., James, W-P.T. 1998. The mineral content of mexican fruits and vegetables. Journal of Food Compasstion and Analysis 11,340-356.
Skujins, S. 1998. Handbook for ICP-AES (Varian-Vista). A short Guide To Vista Series ICP-AES Operation. Varian Int. AG, Zug, Version 1.0, Switzerland

Smith, K. T. 1988. Trace minerals in foods. New York: Marcel Dekker.

Smith. G. C., Clegg, M.S., Keen, C.L., and Griventi, L. E. 1996. Mineral values of selected plant foods common to sounthern Burkina Faso and to Niamey, Niper,West Afrika, Int. J. Food Sci Nutr. 47, 41-33

Şimşek,A., Aslantaş,R. 1999. Composition of hazelnut and role in human nutrition (Fındı ğın bileşimi ve insan beslenmesi açısından önemi). Gıda 24(3), 209-216. (in Turkish)

Wiseman, J. (Ed.). 1987. Feeding of Non-ruminant Livestock. (Collective edited work by the research staff of the Département de l'Élevage des Monogastriques, INRA, under the responsibility of Jean-Claude Blum. Butterworth. 214 pp.

Recibido: Noviembre 2005 Aceptado: Enero 2006 